\title{
Tenant Satisfaction in Public Housing and its Relationship with Rent Arrears: Majlis Bandaraya Ipoh, Perak, Malaysia
}

\author{
A. Nor Aini Salleh, B. Nor'Aini Yusof, C. Abdul Ghani Salleh, and D. Noraini Johari
}

\begin{abstract}
Rent is a form of revenue obtained by public housing management that is used towards the management and maintenance of public housing. Without rent collection, there is no revenue. It is therefore critical that research on rent arrears be undertaken to understand the extent of the problem. This paper studies the relationship between tenant satisfaction and rent arrears prevalent amongst MBI public housing tenants. Data for the study was obtained through questionnaire distribution on $659 \mathrm{MBI}$ public housing tenants using the strata sampling technique. The study found that tenant satisfaction is related to the rent arrears problem. Although the payment of rent is commonly focused on the ability to pay rent apparent amongst tenants, the fact remains that tenant satisfaction must also be considered by the public housing management in order to increase the payment of rent by tenants.
\end{abstract}

Index Terms - Rent Arrears, Public Housing, Tenant Satisfaction, Logistic Regression Analysis

\section{INTRODUCTION}

The management of public housing by the government in most countries is often labeled poor maintenance, low rentals and more often than not, tenants are unsatisfied with their dwelling units. These factors contribute towards the general decline of public housing (Hegedus \& Mark, 1994). This is further exacerbated by the high vacancy rates resulting in many abandoned units being left to rot. High vandalism rates in public housing also contribute to the high maintenance cost. The problem could not be overcome due to a lack of funds faced by the housing management. One of the main reasons leading to this financial crisis is the rent arrears faced by the management (Oxley \& Smith, 1996). The public housing management in Malaysia is also not exempt from problems in managing their units. The root causes leading to

Manuscript received October 22, 2010. This work was supported in part by the Universiti Sains Malaysia for the research grant (1001/Vot/PPBG/841015).

NA Salleh is a senior lecturer in University Teknologi Mara Perak. She is now a full time $\mathrm{PhD}$ student with the University Sains Malaysia. (corresponding author phone: +60-19-3802535; e-mail: noinsphd07@ gmail.com).

N. Yusof is an associate professor in Universiti Sains Malaysia. She is now with the School of Housing, Building \& Planning in Universiti Sains Malaysia, Penang, Malaysia (e-mail: norainy@gmail.com).

A.G Salleh is a professor in Universiti Sains Malaysia. He is now with the School of Housing, Building \& Planning in University Sains Malaysia, Penang, Malaysia (e-mail: Sghani@usm.my).

N. Johari is a senior lecturer in University Teknologi Mara Perak. She is now with the Faculty of Architecture, Planning \& Surveying in University Teknologi Mara Perak, Bandar Seri Iskandar, Perak (e-mail:ininjasmin@yahoo.com) this problem have been identified as vandalism, repairs and most glaringly, is the high rent arrears rates faced by public housing managements (Jabatan Perumahan Negara, 2007 and Dewan Bandaraya Kuala Lumpur, 2007).

Rent arrears are debts incurred by the tenants to the management due to delays in paying rent. The payment of rent should be done in accordance with the tenancy agreement signed. Delays in paying rent will result in rent arrears (Sethu, 1986). Rent arrears in public housing is a problem faced by almost every country in the world. The phenomenon of high rent arrears is very disturbing especially to the government. Even though rent arrears problem in most public housing is endemic, not many empirical studies on rent arrears have been done in the past. The root causes for rent arrears manifested in low income tenants are often attributed to the ability to pay rent. Some quarters have even suggested that they are caused by poor management. Some have attributed rent arrears to low tenant satisfaction. This research will therefore look into how far tenant satisfaction affects rent arrears in public housing in Majlis Bandaraya Ipoh (MBI).

\section{Public Housing In MaJlis Bandaraya IPOH}

Public housing programs are construction projects undertaken by the Ministry of Housing and Local Government (KPKT) via the National Housing Department (JPN). Various public housing projects have been implemented by the government amongst which are Projek Perumahan Awam Kos Rendah (PAKR), Projek Perumahan Rakyat (PPR) Bersepadu (MTEN), Projek Perumahan Rakyat (PPR) Disewa Dasar Baru and Projek Perumahan Rakyat (PPR) Dimiliki Dasar Baru (JPN,2007). Since there are so many public housing projects offered by the government, this research has therefore benchmarked that only those public housing let out and managed by the local authorities (LA) are included in the study. In Malaysia, only two LAs have been identified to manage their public housing directly namely, Dewan Bandaraya Kuala Lumpur and Majlis Bandaraya Ipoh (MBI) but only MBI has been chosen as a case study due to several limitations.

Majlis Bandaraya Ipoh or MBI is a local authority entrusted with the management of a designated area in Ipoh, Perak. Previously known as Ipoh Sanitary Board, MBI was formed in 1893. In 1962, an administrative reshuffling transformed this LA from being a sanitary board into Majlis Perbandaran Ipoh and again upgraded into Majlis 
Perbandaran Ipoh, a city council on $27^{\text {th }}$ May 1988. This auspicious occasion was declared by His Royal Highness Sultan Azlan Muhibbuddin Shah Ibni AlMarhum Sultan Yussuf Izzuddin Shah Ghafarullahulah. MBI's administrative area covers 642.57 square kilometres (MBI, 2007).

Public housing managed by MBI covers five public housing areas namely Kinta Heights Public Housing, Jalan Silang Public Housing, Jalan Bijih Timah Public Housing, Sungai Pari Towers Public Housing and Waller Court Public Housing. All five public housing areas are located within Ipoh City limits whereby all aspects of management and maintenance of the public housing units fall under the jurisdiction of MBI.

\section{THEORETICAL FRAMEWORK ON RESIDENTIAL SATISFACTION}

Theoretically, housing is often viewed as an entity involving a large number of units displaying aspects such as physical quality, location, standard of services offered by the government and private owners as well as neighbourhood characteristics (Chi \& Griffin, 1980). The physical entity of housing ties down a person or family to personal services and relationships. A housing that fulfils one's daily needs provide a high satisfaction rate to residents (Lord \& S.Rent, 1987). Satisfaction towards the living conditions means no complaints are made since the housing units fulfil the needs and aspirations of the residents (Abdul Ghani, 2008). Satisfaction towards the housing environment reflects residents' reaction towards their living environment. In this context, environment does not merely refer to the physical and environmental components of housing but also covers social factors and economic conditions (Kellekci \& Berkoz, 2006). Husna and Nurizan (1987) iterated that the cause for prevailing dissatisfaction was unfulfilled needs or the existence of housing deficit among households. The high disssatisfaction rate towards housing will pose a negative impact on the well-being of a family (Husna \& Nurizan, 1987). Some of the negative impact are the residents moving away, poor neighbourhood and community development and under-achievement in the children's education (James et al., 2008). It is apparent that Husna and Nurizan's study (1987) supports McCray and Day's (1977) opinion that relates housing satisfaction to Maslow's Theory of Needs. Maslow's theory has been used to evaluate individual needs towards housing. McCray and Day's (1977) study found that when housing needs are fulfilled, the individual will indirectly be satisfied with his/her house. In general, housing has been accepted as a main component towards a quality life (Ginsberg \& Churchman, 1984).

The concept of housing satisfaction is multi layered. Ramdane and Abdullah (2000) and Galster (1985) display similar views on the concept of housing satisfaction based on their observation on past studies. In their opinion, the concept of housing satisfaction has been used for four major objectives: firstly; it is the key to predict an individual's perception on the overall quality of life. Secondly; it is also an indicator of individual mobility which later changes the demand on housing and influences surrounding area change. Thirdly; it is used as an ad hoc measurement of private sector development success. Fourthly; as an evaluation tool to measure residents' acceptance of prevailing shortcomings for existing surrounding area development; and finally to act as a variable in determining the relationship between the resident's background and his attitude towards mobility.

Generally, an owner is said to have a high satisfaction level towards housing as compared with a tenant. This has been proven through a study carried out on European countries by Elsinga \& Hoekstra (2005). This empirical study was divided into 3 groups of countries; firstly countries whose lingua franca was English - Ireland and England; secondly countries with an established tenanted housing sector namely Austria, the Netherlands and Denmark; and finally; Southern European countries namely Spain, Italy and Greece. The study was done to prove whether housing ownership will give more satisfaction to owners or tenants. Findings of the study indicated that house ownership gives more satisfaction to the owners in terms of safety, power or freedom to make decisions and also a symbol of prestige and personality. This study was compatible with the findings of Apgar's (2004) study which also indicated that owners have a higher housing satisfaction as compared to tenants.

Although housing ownership gives a higher satisfaction to owners, not everybody can enjoy comfortable housing. It is only within the reach of those who can afford it, the rest are relegated to renting in more affordable housing areas. Hence, it is important that research is conducted to find out housing satisfaction among tenants because satisfied tenants lead to full occupancy, low cost of tenant procurement, reduction in complaints being filed against the management and a decrease in rent arrears (Gubbay, 1999). Findings of a study done in the past has led to the formulation of a study structure to measure housing satisfaction which is divided into four main categories amongst which are satisfaction towards the dwelling unit, satisfaction towards neighbourhood qualities, satisfaction towards the management and satisfaction towards the services provided by the housing management whether by the developer or by the land owner; and satisfaction towards the facilities and amenities available in the dwelling unit and its surrounding area. The differing socio-economic backgrounds of residents also contribute to different levels of satisfaction towards housing (Ukoha \& Beamish, 1997). The following is a detailed explanation on the four different structures influencing the level of satisfaction towards housing:

\section{A. Building Features and Conditions}

Satisfaction towards housing that is related to dwelling units is apparent from the building conditions and the features manifest in the buildings (Ukoha \& Beamish, 1997). Onibokun (1974) has classified building conditions and features as dwelling subsystems to the human habitat that influence the level of housing satisfaction. This view was further supported by McCray and Day (1977) who mentioned that housing construction rarely refer to the needs and types of families who are going to inhabit the houses whereas these criteria are critical in the establishment of human habitats. Different types of buildings for example detached house, 
terrace house and flats give different levels of satisfaction to their residents. The level of satisfaction towards housing differs according to the type of dwelling occupied by the household. Studies done in three local authority administrative areas in London during the London housing study in 2001 found that tenants living in high rise flats most often face the problem of rent arrears as compared to those in low rise flats (www.renewal.net). This statement is proven through findings of past studies done by Rent and Rent (1978), Hourihan (1984), Husna and Nurizan (1987), Ukoha and Beamish (1997)and Varady and Preiser (1998).

A study done by Lane and Kinsey (1980) found that housing characteristics are critical factors in determining housing satisfaction as compared to the residents' demographics. They found that shifting will occur if the residents are not satisfied with the house they are residing in. On the contrary, a different finding was found by Peek and Stewart (1985) who reported that besides building features, demographic factors also influence the satisfaction level of residents.

The subject matters studied by past researchers were related to housing characteristics, among them the number of bedrooms; the sizes of bedrooms, kitchens, bathrooms, study areas, living rooms; the level of privacy; the location of bedrooms, staircases, living rooms, dining areas, kitchens; and the overall size of the house. Items studied may differ according to the researcher as per their researches. A good building structure is an important indicator determining the quality of housing and the value of a dwelling (Kutty, 1999). Three dimensions of housing quality are viewed from the internal aspects of a dwelling unit, its external aspects as well as its surrounding area aspects on the whole (Duncan (1971) from Ramdane \& Abdullah, 2000). According to Elsinga and Hoekstra (2005), the higher quality a dwelling is, the higher the resident's satisfaction is towards it. They reiterated that housing quality must not be assessed based on one variable only, the fact is various aspects must be studied whether on its objective dimensions or subjective dimensions. Kain \& Quigley (1970) divided housing quality into 5 critical factors namely basic housing quality factor; dwelling unit quality factor; surrounding property quality factor; non-residential land use factor; and structural average quality factor. According to Kain \& Quigley (1970), basic housing quality factor refers to the index used to measure the housing surrounding area's external physical quality. Dwelling unit quality factor is assessed from the structural aspects and internal hygiene of the dwelling unit; whilst surrounding property quality factor is assessed from the general cleanliness of the surrounding area, its ambience and landscaping. The factor of quality for non-residential uses is measured from the effects of industrial and commercial uses in residential areas. The effects are assessed based on the level of discernible noise, air quality and traffic flow in the area. The structural average quality factor is assessed based on the structural quality on the building facade.

\section{B. Socio-economic Characteristics}

The study on the level of satisfaction towards housing also looks into the socio-economic profile of residents. An example of such a study is one done by Ukoha and Beamish
(1997). Research on the profile of residents must be considered because households with different socio-economic backgrounds have different levels of aspiration, tolerance and psychology on satisfaction towards housing (Galster, 1987). This opinion tallies with the findings of a study by Bruin and Cook (1997) on matriachal low income single families which indicated that personality traits are good precursors to satisfaction towards housing (Bruin \& Cook, 1997).

The level of satisfaction towards housing also differs according to ethnic backgrounds. Past research done by Husna and Nurizan (1987) on low income residents at Dewan Bandaraya Kuala Lumpur public housing have found a difference in satisfaction towards housing among different ethnic backgrounds. They found that the Malays have the lowest level of satisfaction towards housing as compared to the Chinese and Indians. Some of the items studied under this variable are income and also the level of education attained by occupants. The study done by Husna and Nurizan (1987) found that residents who attained a low level of education indicated a high level of satisfaction towards all aspects of their dwellings (except neighbourhood aspects) as compared to those with higher level of education. Their study also found that income do not display any relationship to the level of satisfaction for all aspects of housing.

A study carried out by Galster (1987) found that older residents have a lower level of aspiration but a higher level of tolerance towards any shortcomings as compared to the younger residents. Rent and Rent (1978) posted different findings from Galster's (1987) whereby the former found that the level of aspiration, self respect and seclusion have no bearing on the residents' level of satisfaction towards their housing but conversely, current living satisfaction influences the level of housing satisfaction. Their study also proved that house owners have a higher level of satisfaction as compared to tenants and most owners live in detached houses.

\section{Neighbourhood Qualities}

Low-income households based on limited income chose dwellings that suit them. Factors like accessibility to the workplace, schools and shops are considered. Usually, areas inhabited by this particular sector of the population were chosen based on their social status (Troy, 1973). According to Troy (1973), when a household lives in an area that fits their social status, their level of satisfaction towards their social surrounding will also increase. Kollekci and Berkoz (2006) added that satisfaction towards the housing surrounding reflects the residents' reaction towards the area inhabited. Abdul Ghani (2008) concurred with Kollekci and Berkoz (2006) on the view which stated that the reaction shown by residents in a housing area is the basis to the feedback for policy formulation.

Studies related to aspects of the surrounding area were prolific and among the empirical studies done was one on 6,000 respondents in eight municipalities in Sweden. This study found among the top 10 neighbourhood qualities are: security and surrounding area control; good public transport; proximity to commercial areas; building exteriors with high aesthetic values; proximity to open spaces; not noisy and no traffic congestion; good reputation; good quality along the 
building surrounding; proximity to town centres and a conducive environment (Bjorklund \& Klingborg, 2005). Research done by Savasdisara et al., (1989) looked into items such as trust in neighbours; friendly neighbours; helpful neighbours; trustworthy neighbours; neighbours with mutual interests, socio-economic status of neighbours, the level of education attained and types of occupation as indices to measure the level of satisfaction towards the neighbourhood (Savasdisara et al., 1989).

Abdul Ghani (2008) also reasearched the level of housing satisfaction in low cost housing areas built by the private sector. He looked into two important aspects influencing individual quality of life namely satisfaction towards housing and its surrounding area. Findings of the study indicated that neighbourhood factors are the most dominant factors in determining the level of satisfaction towards housing. The factors contributing to a low level of satisfaction were related to neighbourhood facilities and surrounding area and these are poor public transport; lack of children's playgrounds, multi purpose hall, parking areas, safety and facilities for the disabled. This was because most private developers were not motivated to provide neighbourhood facilities and a better environment in order to increase profitability.

Ramdane and Abdullah (2000) found in their study that there are three factors affecting satisfaction towards housing: dwelling unit, neighbourhood and community services factors. Neighbourhood factors impacts highly on overall satisfaction towards housing. Factors studied under aspects of neighbourhood were the level of privacy achieved by the residents, distance to the workplace, location of schools and infrastructural services and amenities (Ramdane \& Abdullah, 2000).

Kearney (2006) studied in detail the effect of form of housing development on neighbourhood satisfaction from the viewpoints of effects of density and the surrounding environment. Their study found that negative feelings towards high density was not caused by the existence of high density developments but it was caused by the existence of unattractive cityscape and obstruction of view due to the high density development. This means that neighbourhood satisfaction depends critically on the actual lot size; residents who cannot see their neighbours' houses and have a better natural view feel that their lots are not so small and do not face privacy problems or feel that the neighbours were too close to their house. Hence, they feel that high density developments need natural view to increase satisfaction towards the neighbourhood (Kearney, 2006).

\section{The Management}

The role played by the management in managing the housing environment is crucial especially in tenanted housing. Effects of management can be discerned through the way tenant selection was carried out, implementation of the law, methods and times of rent collection, hygiene, maintenance, security and tenant relations (Ahlbrandt \& Brophy, 1976). The relationship between the housing management and the tenants pose a large influence on tenants' housing satisfaction (James et al., 2008). Additionally, repair services carried out by the management is said to influence the level of tenant satisfaction towards their dwellings. Matters considered in aspects of repairs were the quality of services offered and the time taken by the management in handling tenants' complaints (P.Varady \& Carrozza, 2000; Ukoha \& Beamish, 1997). Husna \& Nurizan (1987) placed the aspects of plumbing and building repairs, electrical wiring, water supply, garbage disposal and security as variables studied as management factors influencing the level of satisfaction among residents of low cost housing managed by DBKL.

A detailed study on the aspect of management has been carried out by Paris \& Kangari (2005) in the Defoors Ferry Manor and Moore Mills affordable housing located in Atlanta. The study was done to help develop a Decision Support System framework for the property managers. The study on the level of tenant satisfaction towards the management looked into 18 strategic management issues impacting residents namely: satisfaction towards management satff; satisfaction towards the tenant selection procedures and processes; implementation of the law; friendliness of the management; the time taken to act on tenants' complaints; tolerance in handling issues; teamwork among the staff; the quality of repair works upon completion; building quality; hygiene quality in the building unit; hygiene quality in the overall dwelling area; environmental security; unit security; whether or not will ask friends to stay in the same housing area; overall quality of maintenance carried out by the management and overall satisfaction towards the dwelling unit. Findings of their study indicated that the 18 aspects studied have a strong relationship with the level of tenant satisfaction.

\section{Methodology}

The entire population of this study comprises all Majlis Bandaraya Ipoh (MBI) tenants totalling 1,008 units. The list of tenants residing in the public housing was obtained from MBI public housing management. Hence, the study samples were a portion of housing units' tenants selected by the researcher through two-tier strata sampling method. Samples were stratified into types of housing and types of tenants whether facing rent arrears or otherwise. This totals up the overall samples into 350 persons (Sekaran, 2003). This study used face-to-face self-administered questionnaires using pencil and paper. Even though this method of questionnaire distribution was more costly, it has been touted by Vaus (2002) as being the most effective method in terms of feedback procured as compared to questionnaire distribution methods using the internet and by post. Questionnaire distribution was done on 659 selected samples but only 301 feedback was procured from public housing tenants. The questionnaire was divided into a few main sections which are Section A: Tenant Background; Section B: Information on Tenant's Renting Ability; Section C: Satisfaction Towards Housing, Surrounding Area and Management; Section D: Rent Arrears Among Public Housing Tenants. Section A was intended to collect information on the backgrounds of heads of households in public housing. Section B was the section devised to study the level of financial abilities of public housing tenants. Meanwhile, Section $\mathrm{C}$ worked at finding out 
how far the level of tenant satisfaction towards housing and services provided by the public housing management. Section D was formulated to determine in detail matters related to rent arrears faced by tenants. The level of tenant satisfaction towards housing was measured using the five-point Likert Scale which are 1 - Very Dissatisfied, 2 Dissatisfied, 3 - Not Sure, 4 - Satisfied, 5 - Very Satisfied. The development of this questionnaire was the product of a combination between past researches from various countries and later reconstructed to achieve the researcher's aims. The use of instruments or measuring tools with high credibility and trustworthiness towards the collection of data required in the research was something that has been given due weightage. The Cronbach's Alpha test carried out found that for building features construct, the overall Alpha value of 0.9 was ascertained while for building quality construct, there was an Alpha value of 0.87 . For neighbourhood aspects, the Alpha value obtained was 0.749 and lastly the Alpha value for management aspects was 0.748 . All these pointed out that data measured for tenant satisfaction was at a good level as observed by Chua (2006) and Pallant (2005).

\section{RESUlTS AND DISCUSSION}

As explained earlier, this research aims at studying the extent of the relationship between rent arrears and tenant satisfaction towards housing in general. To that end, data were analysed to achieve the aims of the research. Findings of the research are as follows:

\section{A. The Socio-economic Profile of MBI Public Housing Tenants}

Analysis revealed that there were a total of $53.2 \%$ male respondents (160 persons) and 46.8\% (141 persons) female respondents. The ages of the respondents vary between 21 years and above until more than 70 years old. Thus it can be seen that the majority of MBI public housing tenants were aged between 46 years until 60 years representing $42.2 \%$ (127 persons) from the entire respondent count. The major ethnic group renting here was Chinese at $45.8 \%$ (138 persons) followed by Indian tenants at $26.2 \%$ ( 79 persons). Malay tenants numbered at $17.6 \%$ (53 persons) and other ethnic groups including Punjabis and Indian-Muslims totalled $10.3 \%$ (31 persons). This research differs from findings obtained by Mohit et al., (2010) and Husna and Nurizan (1987) who did research on low cost public housing in Kuala Lumpur and found that the majority of tenants were Malays followed by Chinese and Indians. However, the data dispersion based on ethnic groups obtained here is in accordance with statistical data gathered by MBI. Data collected by MBI also showed that the major ethnic group tenants were Chinese, second highest number of tenants were the Indians followed by the Malays and the minority was others (MBI, 2007). Most of MBI's public housing tenats have occupied these housing areas for more than 20 years that is $34.6 \%$ (104 families). Those who rented between 11 years until 20 years were at about $23.6 \%$ (71 families) while those who rented between 6 years until 10 years were $14 \%$ (42 families). Tenants renting for periods between 3 to 5 years were at $15.3 \%$ (46 persons) and only 37 families or
$12.3 \%$ rented for a period of between 1 to 2 years. The study found that the majority of tenants at $36.5 \%$ (110 persons) finished primary level of education whilst $46.2 \%$ (139 persons) finished secondary education. Uneducated tenants numbered $14.6 \%$ (44 persons), only $2 \%$ (6 persons) attained college education and one respondent finished until madrassa education. Tenants' household incomes showing the highest number of respondents were between RM601 until RM900 per month owned by 77 households $(25.6 \%)$. This was followed by households with incomes between RM1201 until RM1500 per month (19.3\%). Only a small percentage of households have incomes between RM0 - RM300 per month at $6.3 \%$ (19 families). There were also households with incomes exceeding RM1501 per month at 13.6\% (41 families). It may be concluded that the household incomes of MBI public housing tenants hover between RM600 until more than RM1500 per month.

\section{B. Level of Tenant Satisfaction towards Building Features}

Table 3.0 shows mean score of tenant satisfaction towards building features at MBI public housing. Mean score of tenant satisfaction towards building features was between 2.89 (size of children's play space) until 3.87 (location of living area) at a scale of $1-5$. The higher the mean score of tenant satisfaction towards building features, the higher is the level of tenant satisfaction towards the building features of the buildings they occupy. The physical characteristics of housing influence the level of resident satisfaction towards their housing (Ginsberg \& Churchman, 1984). Analysis shows that almost all building features of MBI public housing achieved a high tenant satisfaction mean score value. This study supports the study done by Abdul Ghani (2008) who found that residents of low cost housing in Pulau Pinang and Kuala Terengganu were satisfied with the building features of the houses they were residing in based on mean score 3.12 for Pulau Pinang and 3.06 for Kuala Terengganu. However, the study done by Husna and Nurizan (1987) contradicted with this study whereby they found that a large number of their study's respondents were dissatisfied with the characteristics of their dwelling units. This study found that two building features achieved a low mean score namely size of children's play space (2.89) and size of study area (3.00). This analysis concurs with a study done by Ukoha and Beamish (1997) on public housing in Abuja, Nigeria which also found that size of children's play space (1.83) and size of study area (1.74) also scored a low mean score. Nevertheless Ukoha and Beamish's (1997) study found that on the whole, residents in this public housing were dissatisfied with their housing.

TABLE 3.0: TENANT SATISFACTION TOWARDS BUILDING FEATURES

\begin{tabular}{|l|c|c|c|c|c|c|c|}
\hline $\begin{array}{c}\text { Building Characteristics } \\
\text { Elements }\end{array}$ & $\begin{array}{c}\text { Sample } \\
(\mathrm{n})\end{array}$ & 1 & 2 & 3 & 4 & 5 & Mean \\
\hline Location of Staircase & 301 & 6 & 32 & 11 & 230 & 22 & 3.76 \\
\hline Location of Living Room & 301 & 3 & 19 & 11 & 249 & 19 & 3.87 \\
\hline Location of Kitchen & 301 & 8 & 50 & 14 & 217 & 12 & 3.58 \\
\hline Location of Dining Area & 301 & 16 & 61 & 16 & 198 & 10 & 3.42 \\
\hline Size of Living Room & 300 & 7 & 65 & 15 & 199 & 14 & 3.49 \\
\hline Size of Kitchen & 300 & 18 & 95 & 14 & 164 & 9 & 3.17 \\
\hline Size of Bedroom & 301 & 5 & 40 & 13 & 228 & 15 & 3.69 \\
\hline
\end{tabular}




\begin{tabular}{|l|l|l|l|l|l|l|l|}
\hline Size of Bathroom & 301 & 16 & 65 & 12 & 201 & 7 & 3.39 \\
\hline Size of Study Area & 300 & 22 & 87 & 63 & 125 & 3 & 3.00 \\
\hline $\begin{array}{l}\text { Size of Children's Play } \\
\text { Space }\end{array}$ & 301 & 24 & 00 & 65 & 108 & 4 & 2.89 \\
\hline Number of Bedrooms & 299 & 14 & 91 & 15 & 169 & 10 & 3.23 \\
\hline Level of Privacy & 301 & 16 & 52 & 30 & 192 & 11 & 3.43 \\
\hline Overall Size of House & 301 & 10 & 52 & 26 & 199 & 14 & 3.51 \\
\hline Overall Mean & 301 & & & & & & 3.42 \\
\hline
\end{tabular}

Note: $1=$ Very Dissatisfied, $2=$ Dissatisfied, $3=$ Not Sure, $4=$ Satisfied, $5=$ Very Satisfied

\section{Level of Tenant Satisfaction towards Building Quality}

Based on results of analysis on tenant satisfaction in relation to building quality found that the lowest mean score value was the quality of external public housing painting (2.61) followed by quality of internal building painting (2.80) and building corridor lighting (2.92). These findings further enforced the researcher's opinion who found that every MBI public housing building appeared deteriorated. Studies done by Ukoha and Beamish (1997) and Onibokun (1974) also found that most respondents were dissatisfied with the qualities of internal and external building painting. During the questionnaire study, the researcher found that most lighting provided at building corridors were not functioning. This shows that MBI public housing was not well maintained However, this study was in contradiction with findings of a study done by Varady and Carroza (2000) which indicated that although most of the public housing units in Cincinatti were dilapidated; their residents were still satisfied with their housing. Apart from the three elements discussed above, Table 3.1 shows a high mean score of tenant satisfaction towards building quality of between 3.12 (number of sockets) to 3.66 (quality of floor).

TABLE 3.1: TENANT SATISFACTION TOWARDS QUALITY OF BUILDING

\begin{tabular}{|c|c|c|c|c|c|c|c|}
\hline $\begin{array}{l}\text { Building Quality } \\
\text { Elements }\end{array}$ & ample & 1 & 2 & 3 & 4 & 5 & Mean \\
\hline & 301 & 10 & 55 & 21 & 201 & 14 & 3.51 \\
\hline $\begin{array}{l}\text { Internal Construction } \\
\text { Quality }\end{array}$ & 30 & 12 & 45 & 25 & 206 & 13 & 3.54 \\
\hline Wall Quality & 29 & 3 & 47 & 17 & 216 & 12 & 62 \\
\hline Floor Quality & 301 & 6 & 39 & 18 & 226 & 12 & 3.66 \\
\hline Window Quality & 297 & 17 & 52 & 16 & 204 & 8 & 3.45 \\
\hline Corridor Lighting & 299 & 38 & 98 & 18 & 139 & 6 & 2.92 \\
\hline Internal Paint Quality & 301 & 24 & 132 & 29 & 112 & 4 & 2.80 \\
\hline External Paint Quality & 301 & 32 & 147 & 30 & 89 & 3 & 2.61 \\
\hline Door Quality & 300 & 16 & 71 & 16 & 191 & 6 & 3.33 \\
\hline Plumbing Qu & 299 & 21 & 80 & 21 & 167 & 10 & 3.22 \\
\hline Wate & 301 & 20 & 68 & 15 & 188 & 10 & 3.33 \\
\hline Wirin & 29 & 14 & 63 & 21 & 194 & 7 & 3.39 \\
\hline Air Quality & 300 & 8 & 44 & 18 & 216 & 14 & 3.61 \\
\hline Number of Sockets & 298 & 16 & 103 & 15 & 156 & 8 & 3.12 \\
\hline Overall Unit Quality & 299 & 8 & 56 & 39 & 191 & 5 & 3.43 \\
\hline verall Mean & 301 & & & & & & 3.30 \\
\hline
\end{tabular}

Note: $1=$ Very Dissatisfied, $2=$ Dissatisfied, $3=$ Not Sure, $4=$ Satisfied, $5=$ Very Satisfied

\section{Level of Tenant Satisfaction towards Neighbourhood Aspects}

Cleanliness and hygiene in public housing often become the bone of contention among residents of these housing units. Findings obtained through this study indicated that tenant satisfaction towards aspects of hygiene achieved the lowest mean score value at 2.47. Tenants' lackadaisical attitude towards caring for hygiene and their mentality of expecting someone else to clean up after them contributed to the bulk of the problem. This was because the researcher found that regular garbage collection is being carried out by the MBI management. Tenant perception towards their public housing surrounding area security also scored a low mean value of 2.80. The study's findings echoed those found by Mohit et al., (2010) and Parkes et al., (2002) that indicated that most respondents in their study areas were not very satisfied with the security and crime prevention features in their neighbourhoods. Most of MBI's public housing areas were located within Ipoh city which is a strategic location; hence scoring the highest mean score value of 4.19 for public housing location. This was followed by the short distance of public housing to main shopping centres (4.09). The close proximity of shopping centres to public housing areas enables tenants to go shopping on foot. On top of that, ample modes of public transportation further facilitate tenants' mobility. Accessibility and public transportation facilities were proven to have impacted positively on tenant satisfaction towards housing; simultaneously raising the environmental quality (Kellekci \& Berkoz, 2006). Table 3.2 shows the overall mean value for building features.

TABLE 3.2: TENANT SATISFACTION TOWARDS NEIGHBOURHOOD FEATURES

\begin{tabular}{|l|r|r|r|r|r|r|r|}
\hline \multicolumn{1}{|c|}{$\begin{array}{c}\text { Neighbourhood } \\
\text { Elements }\end{array}$} & Sample & $\mathbf{1}$ & $\mathbf{2}$ & $\mathbf{3}$ & $\mathbf{4}$ & $\mathbf{5}$ & Mean \\
\hline $\begin{array}{l}\text { Location of Dwelling } \\
\text { Unit }\end{array}$ & 300 & 3 & 12 & 6 & 183 & 96 & 4.19 \\
\hline Neighbourhood Relations & 301 & 4 & 15 & 14 & 213 & 55 & 4.00 \\
\hline Distance to Workplace & 300 & 2 & 13 & 31 & 210 & 44 & 3.94 \\
\hline $\begin{array}{l}\text { Distance to Shopping } \\
\text { Areas }\end{array}$ & 301 & 2 & 13 & 5 & 217 & 64 & 4.09 \\
\hline Secure Environment & 301 & 51 & 102 & 23 & 105 & 20 & 2.80 \\
\hline Public Transportation & 301 & 4 & 24 & 21 & 204 & 48 & 3.89 \\
\hline Distance to Schools & 300 & 1 & 8 & 18 & 228 & 45 & 4.03 \\
\hline Landscaping & 297 & 18 & 90 & 32 & 137 & 20 & 3.17 \\
\hline Clean Environment & 300 & 69 & 122 & 15 & 87 & 7 & 2.47 \\
\hline Building Image & 301 & 28 & 88 & 36 & 137 & 12 & 3.06 \\
\hline Parking Facilities & 299 & 16 & 69 & 23 & 172 & 19 & 3.36 \\
\hline $\begin{array}{l}\text { Proximity to Police } \\
\text { Services }\end{array}$ & 300 & 11 & 30 & 31 & 196 & 32 & 3.69 \\
\hline $\begin{array}{l}\text { Proximity to Recreational } \\
\text { Facilities }\end{array}$ & 301 & 8 & 26 & 20 & 204 & 43 & 3.82 \\
\hline Overall Mean & 301 & & & & & & 3.58 \\
\hline
\end{tabular}

Note: $1=$ Very Dissatisfied, $2=$ Dissatisfied, $3=$ Not Sure, $4=$ Satisfied, $5=$ Very Satisfied

\section{E. Tenant Satisfaction towards Public Housing Management}

Tenant satisfaction towards services provided by the public housing management on the whole scored a high mean value. This statement is supported by a study done by Ahlbrandt dan Brophy (1976) which found that tenant satisfaction had a positive correlation with the management 
pattern adopted by public housing management. In other words, increased performance by the management will also influence overall tenant satisfaction to increase. This is apparent from the mean score value for the tenants which were mostly exceeding 3.0. Findings of this study correspond with findings by Husna and Nurizan (1987) that revealed that most residents of Dewan Bandaraya Kuala Lumpur public housing were satisfied with the services offered to them. However, the time taken by the management to act on complaints gave a low mean score value of 2.64. At the time the questionnaire study was carried out, tenants were generally complaining that MBI took so long to act on their complaints that tenants had to carry out the repairs themselves. Varady and Carroza (2002) as well as Ukoha and Beamish (1997) both reported corresponding findings whereby the lowest mean score for aspects of housing management was feedback obtained by the public housing management for repair works (1.66). The overall tenant satisfaction towards services offered by the housing management may be referred to in Table 3.3.

TABLE 3.3: TENANT SATISFACTION TOWARDS SERVICES OFFERED BY THE HOUSING MANAGEMENT

\begin{tabular}{|l|r|r|r|r|r|r|r|}
\hline \multicolumn{1}{|c|}{ Services Elements } & Sample & $\mathbf{1}$ & $\mathbf{2}$ & $\mathbf{3}$ & $\mathbf{4}$ & $\mathbf{5}$ & Mean \\
\hline Implementation of the Law & 301 & 7 & 44 & 61 & 170 & 19 & 3.50 \\
\hline Tenant Selection & 300 & 9 & 55 & 36 & 181 & 19 & 3.49 \\
\hline $\begin{array}{l}\text { Friendliness of the } \\
\text { Management }\end{array}$ & 301 & 5 & 38 & 32 & 204 & 22 & 3.66 \\
\hline Time taken on Complaints & 299 & 51 & 99 & 64 & 78 & 7 & 2.64 \\
\hline Repairs Provided & 299 & 21 & 67 & 78 & 120 & 13 & 3.12 \\
\hline Garbage Collection & 300 & 29 & 58 & 15 & 183 & 15 & 3.32 \\
\hline Current Rental & 300 & 4 & 16 & 12 & 225 & 43 & 3.96 \\
\hline Mode of Rent Payment & 300 & 4 & 36 & 10 & 224 & 26 & 3.77 \\
\hline Time of Rent Payment & 299 & 1 & 24 & 16 & 233 & 25 & 3.86 \\
\hline Rent Payment Advice & 301 & 3 & 25 & 39 & 208 & 26 & 3.76 \\
\hline $\begin{array}{l}\text { Implication of Rent } \\
\text { Non-Payment }\end{array}$ & 300 & 3 & 20 & 27 & 224 & 26 & 3.83 \\
\hline Overall Mean & 301 & & & & & & 3.51 \\
\hline
\end{tabular}

Note: $1=$ Very Dissatisfied, $2=$ Dissatisfied, $3=$ Not Sure, 4= Satisfied, $5=$ Very Satisfied

\section{F. Analysis of Relationship between Rent Arrears and Tenant Satisfaction Factor}

To answer the research question of whether rent arrears are related to tenant satisfaction factor in Majlis Bandaraya Ipoh public housing, a logistic regression analysis method has been used in this research. Since the dependent variables for this research are dichotomy data, the logistic regression binary analysis method would be the most suitable method to be used (Wood, 2006). Analysis on the relationship between rent arrears and tenant satisfaction is based on the information obtained from Section $\mathrm{C}$ of the questionnaires for this research. This analysis covers the relationship between tenant satisfaction towards building features, building, environmental or neighbourhood qualities and the housing management aspects; and the nature of their relationships to rent arrears.

The dependent variable for this research is whether or not the tenants have incurred rent arrears. On the other hand, independent variables are tenant satisfaction towards building features; building, environmental or neighbourhood qualities and the housing management aspects. This analysis was done using SPSS version 12. The dependent variable, rent arrears, is divided into two categories namely: never incurred (0) and have incurred (1) as shown in Table 4.0. Table 4.0 indicated that there are 301 research samples and that there were no lost cases.

TABLE 4.0: CODES FOR DEPENDENT VARIABLES

\begin{tabular}{|c|c|}
\hline Dependent Variables & Value \\
\hline Never Incurred & 0 \\
\hline Have Incurred & 1 \\
\hline
\end{tabular}

TABLE 4.1: NULL MODEL

\begin{tabular}{|c|c|c|c|}
\hline \multicolumn{2}{|c|}{ Unweighted Cases(a) } & $\mathbf{N}$ & Percentage \\
\hline \multirow[t]{3}{*}{ Selected Cases } & Included in Analysis & 301 & 100.0 \\
\hline & Missing Cases & 0 & .0 \\
\hline & Total & 301 & 100.0 \\
\hline \multicolumn{2}{|c|}{ Unselected Cases } & 0 & .0 \\
\hline \multicolumn{2}{|c|}{ Total } & 301 & 100.0 \\
\hline
\end{tabular}

a If weight is in effect, see classification table for the total number of cases.

Results of the logistic regression analysis were divided into two step which are: (a) Step 0 (null model) and (b) Step 1 (Block 1: Model with predictor). Table 4.2 shows 58.5 percent of cases have faced rent arrears. Meanwhile, for the model with predictor Table 4.3 shows an increase to 59.5 percent of cases that have faced rent arrears. The Omnibus test as shown in Table 4.4 illustrates integration of the models formed where its value was 0.026 which means that $\mathrm{p}<0.05$. The Omnibus test is also known as the compatibility test. The Hosmer and Lemeshow test (Table 4.6) shows an insignificant Chi Square $\left(\mathrm{X}^{2}=10.457, \mathrm{df}=8, \mathrm{p}=0.234\right)$ with a significant level $\mathrm{p}=0.05$. these findings shows compatibility between the model and the data collected in this study (Tabachnick \& S.Fidell, 2001). Table 4.5 shows the value of $\mathrm{R}$ to the power of two Cox and Snell is 0.036 , meaning only 3.6 percent improvements for the model with predictor as compared with the null model.

TABLE 4.2: PREDICTOR MODEL

\begin{tabular}{|c|c|c|c|c|c|}
\hline \multicolumn{3}{|c|}{ Observed } & \multicolumn{3}{|c|}{ Predicted } \\
\hline & & & \multicolumn{2}{|c|}{ Facing Arrears } & \multirow[b]{2}{*}{$\begin{array}{l}\text { Percentage } \\
\text { Correct s }\end{array}$} \\
\hline & & & $\begin{array}{l}\text { Never } \\
\text { Faced }\end{array}$ & $\begin{array}{l}\text { Have } \\
\text { Faced }\end{array}$ & \\
\hline \multirow{3}{*}{$\begin{array}{c}\text { Step } \\
0\end{array}$} & Facing Arrears & Never Faced & 0 & 125 & .0 \\
\hline & & Have Faced & 0 & 176 & 100.0 \\
\hline & Overall $\mathrm{P}$ & centage & & & 58.5 \\
\hline
\end{tabular}

a Constant is included in the model.

b The cut value is .500

TABLE 4.3: CLASSIFICATION

\begin{tabular}{|c|c|c|c|c|c|}
\hline \multicolumn{3}{|c|}{ Observed } & \multicolumn{3}{|c|}{ Predicted } \\
\hline & & & \multicolumn{2}{|c|}{ Facing Arrears } & \multirow[b]{2}{*}{$\begin{array}{l}\text { Percentage } \\
\text { Correct s }\end{array}$} \\
\hline & & & $\begin{array}{l}\text { Never } \\
\text { Faced }\end{array}$ & \begin{tabular}{|l|} 
Have \\
Faced \\
\end{tabular} & \\
\hline \multirow[t]{3}{*}{ Step 1} & $\begin{array}{l}\text { Facing } \\
\text { Arrears }\end{array}$ & Never Faced & 24 & 101 & 19.2 \\
\hline & & Have Faced & 21 & 155 & 88.1 \\
\hline & Overa & ercentage & & & 59.5 \\
\hline
\end{tabular}

a The cut value is .500

TABLE 4.4: OMNIBUS TEST 


\begin{tabular}{|lc|c|c|c|}
\hline & & Chi-square & df & Sig. \\
\hline Step 1 & Step & 11.070 & 4 & .026 \\
& Block & 11.070 & 4 & .026 \\
& Model & 11.070 & 4 & .026 \\
\hline
\end{tabular}

TABLE 4.5: TABLE OF MODEL SUMMARY

\begin{tabular}{|c|c|c|c|}
\hline Step & $\begin{array}{c}\mathbf{- 2} \text { Log } \\
\text { likelihood }\end{array}$ & $\begin{array}{c}\text { Cox \& Snell R } \\
\text { Square }\end{array}$ & $\begin{array}{c}\text { Nagelkerke R } \\
\text { Square }\end{array}$ \\
\hline 1 & $397.522(\mathrm{a})$ & .036 & .049 \\
\hline
\end{tabular}

a Estimation terminated at iteration number 4 because parameter estimates changed by less than .001 .

TALBE 4.6: HOSMER AND LEMESHOW TEST

\begin{tabular}{|c|c|c|c|}
\hline Step & Chi-square & Df & Sig. \\
\hline 1 & 10.457 & 8 & .234 \\
\hline
\end{tabular}

Table 4.7 shows that only two variables pose a significant influence on tenants having rent arrears that are building quality $(\mathrm{B}=-0.551)$ and neighbourhood $(\mathrm{B}=0.725)$. This means that low tenant satisfaction towards building quality could have raised the level of rent arrears by tenants. This study reinforces the statement by Amerigo and Aragones (1990) which emphasised on the importance of building quality in influencing the level of housing satisfaction.

Neighbourhood aspects also posed a significant influence. Increase in satisfaction towards a public housing neighbourhood could cause rent arrears to rise. This is because good relations among neighbours will inculcate a negative rent payment culture if they realised that no action will be taken by the management on neighbours who have incurred rent arrears. Besides that, the researcher is of the opinion that housing areas located nearby shopping districts will encourage tenants to be spendthrift; hence eating up into the money reserved for rent payment (Ford \& Seavers, 1998). Even though these housing areas are located close by to a police station, MBI tenants have found that the level of security in their areas is low because there are still cases of petty theft and drug addiction in their housing areas. This has led to dissatisfaction among the tenants in the area.

TABLE 4.7: VARIABLES IN THE EQUATION

\begin{tabular}{|ll|r|r|r|r|r|r|}
\hline & & $\mathbf{B}$ & S.E. & Wald & Df & Sig. & $\operatorname{Exp}(\mathbf{B})$ \\
\hline Step & Mean_Building & -.209 & .215 & .947 & 1 & .330 & .811 \\
$\mathbf{1}(\mathbf{a})$ & Mean_quality & $\mathbf{- . 5 5 1}$ & $\mathbf{. 2 7 0}$ & $\mathbf{4 . 1 5 4}$ & $\mathbf{1}$ & $\mathbf{. 0 4 2}$ & $\mathbf{. 5 7 6}$ \\
& $\begin{array}{l}\text { Mean_neigh- } \\
\text { bourhood }\end{array}$ & $\mathbf{. 7 2 5}$ & $\mathbf{. 3 3 5}$ & $\mathbf{4 . 6 7 6}$ & $\mathbf{1}$ & $\mathbf{. 0 3 1}$ & $\mathbf{2 . 0 6 4}$ \\
& Mean_services & .423 & .302 & 1.968 & 1 & .161 & 1.527 \\
& Constant & -1.185 & 1.068 & 1.232 & 1 & .267 & .306 \\
\hline
\end{tabular}

a Variable(s) entered on step 1: mean_building_features, mean_quality, mean_neighbourhood, mean_services.

\section{CONCLUSION}

On the whole, this study has found that MBI public housing tenants are satisfied with the building characteristics and conditions, building quality, building features and the public housing management. However, there are a few variables showing tenant dissatisfaction towards their housing for example size of children's play space (mean value 2.89); interior painting quality (mean value 2.80 ) and exterior painting quality (mean value 2.61 ), surrounding area security (mean value 2.80), clean surrounding area (mean value 2.47) and actions taken by the management on complaints filed by tenants (mean value 2.64). It is therefore crucial that the management pay attention to the dissatisfaction prevalent among their tenants based on the attributes discussed in the foregoing. High tenant satisfaction towards their housing will indirectly increase the overall quality of life. Good management and maintenance of public housing portrays a positive image of public management especially in the public sector and will simultaneously eradicate any negative connotations often labeled on public housing managements.

Results of the logistic regression analysis show that on the whole, tenant satisfaction towards the housing aspects is related to the prevailing rent arrears problem. However, only aspects of building quality and neighbourhood have a significant relationship in this study. The contradictory relationship between aspects of building quality and rent arrears $(\mathrm{B}=-.551)$ explained that good building quality will reduce the rent arrears problem faced by the housing management. Meanwhile, a positive relationship $(B=0.725)$ between neighbourhood qualities and rent arrears shows good neighbourliness could create a negative culture if no harsh action is taken by the housing management on errant tenants.

In conclusion, although rent payment is often related to the issue of the ability of tenants to pay rent and shortcomings by the management, it is nevertheless critical that tenant satisfaction be given due consideration as this study has proven that satisfaction factor also influences the prevailing rent arrears problem.

\section{ACKNOWLEDGMENT}

The researcher wishes to thank Universiti Sains Malaysia for the research grant (1001/Vot/PPBG/841015) approved to carry out this research and to Universiti Teknologi Mara for approving the study leave. Also due thanks are given to all parties involved in the completion of this research especially to the MBI public housing management and tenants.

\section{REFERENCES}

[1] Abdul Ghani, S. (2008). Neighbourhood Factors In Private Low Cost Housing In Malaysia. Habitat International (32), 485-493.

[2] Ahlbrandt, R. S., \& Brophy, P. C. (1976). Management: An Important Element Of The Housing Environment. Environment And Behaviour, $8(4), 505-526$.

[3] Bjorklund, K., \& Klingborg, K. (2005). Correlation between negotiated rents and neighbourhood quality: A case study of two cities in Sweden. Housing Studies, 20(4), 627-647.

[4] Bruin, M. J., \& Cook, C. C. (1997). Understanding Constraints And Residential Satisfaction Among Low-Income Single-Parent Families. Environment And Behaviour, 29(4), 532-553

[5] Chi, P. S. K., \& Griffin, M. D. (1980). Social Indicators For Measuring Residential Satisfaction In Marginal Settlements In Costa Rica. Social Indicators Research, 8, 453-465

[6] Ford, J., \& Seavers, J. (1998). Housing associations and rent arrears : attitudes, beliefs and behaviour. Coventry: Chartered Institute of Housing. 
[7] Galster, G. (1987). Indentifying The Correlates Of Dwelling Satisfaction: An Emprical Critique Environment And Behaviour, 19(5), 539-568.

[8] Ginsberg, Y., \& Churchman, A. (1984). Housing satisfaction and intention to move: Their explanatory variables. Socio-Econ. Plan.Sci, $18(6), 425-431$

[9] Hegedus, J., \& Mark, K. (1994). Tenant satisfaction with public housing management: Budapest in transition. Housing Studies, Vol. $9(3), 315$.

[10] Husna, S., \& Nurizan, Y. (1987). Housing Provision And Satisfaction Of Low-Income Households In Kuala Lumpur. Habitat International, 11(4), $27-38$.

[11] James, R. N., et al. (2008). Sources of Discontent: Residential Satisfaction of Tenants From an Internet Ratings Site. Environment and Behavior, 41(1), 43-58.

[12] Kearney, A. R. (2006). Residential Development Patterns And Neighborhood Satisfaction: Impacts Of Density And Nearby Nature. Environment And Behaviour, 38(1), 112-139.

[13] Kellekci, O. L., \& Berkoz, L. (2006). Mass Housing: User Satisfaction In Housing And Its Environment In Instanbul, Turkey. European Journal Of Housing Policy, 6(1), 77 - 99.

[14] Kutty, N. K. (1999). Determinants Of Structural Adequacy Of Dwelling. Housing Research, 10(1), 27-43.

[15] Lord, J. D., \& S.Rent, G. (1987). Residential Satisfaction In Scattered-Site Public Housing Projects. The Social Science, 24(3), 287-302.

[16] McCray, J. W., \& Day, S. S. (1977). Housing Values, Aspirations, and Satisfactions as indicators of housing needs. Family And Consumer Sciences Research Journal, 5, 244 - 254.

[17] P.Varady, D., \& Carrozza, M. A. (2000). Toward A Better Way To Measure Customer Satisfaction Level In Public Housing: A Report From Cincinnati. Housing Studies, 15(6), 797 - 825.

[18] Parkes, A., et al. (2002). What makes people dissatisfied with their neighbourhoods. Urban Studies, 39(13), 2413-2438.

[19] Ramdane, D., \& Abdullah, A.-A. (2000). Satisfaction Level With Neighbourhoods In Low-Income Public Housing In Yemen. Property Management, 18(4), 230.

[20] Savasdisara, T., et al. (1989). Residential Satisfaction In Private Estate In Bangkok. Habitat International, 13(1), 65-73.

[21] Sekaran, U. (2003). Research Methods For Business: A Skill-Building Approach (4 ed.). India: John Wiley \& Sons, Inc.

[22] Tabachnick, B. G., \& S.Fidell, L. (2001). Using Multivariate Statistics (4 ed.). Needham Heights, USA: Allyn \& Bacon.

[23] Ukoha, O. M., \& Beamish, J. O. (1997). Assessment Of Residents' Satisfaction With Public Housing In Abuja, Nigeria Habitat International, 21(4), 445 - 460.

[24] Wood, E. H. (2006). The internal predictors of business performance in small firms. Small Business And Enterprise Development, 13(3), 441-453.

[25] Rent arrears. (2007, April 11). [Online]. Available: http://www.renewal.net 